\title{
Effect of N-Acetyl-L-Cysteine on Lymphocyte Apoptosis, Lymphocyte Viability, TNF- $\alpha$ and IL-8 in HIV-infected Patients Undergoing Anti-retroviral Treatment
}

\author{
AricioTreitinger $^{1}$, Celso Spada $^{1}$, Ivete Yoshico Masokawa. ${ }^{2}$, \\ Júlio César Vidal Verdi ${ }^{3}$, Mariette Van Der Sander Silveira ${ }^{2}$, \\ Magali Chaves Luis ${ }^{2}$, Marcellus Reis ${ }^{4}$, Silvia Inês Alejandra \\ Cordova de Pires Ferreira ${ }^{5}$, Dulcinéia Saes Parra Abdalla ${ }^{6}$
}

\author{
Federal University of Santa Catarina ${ }^{1}$; Nereu Ramos \\ Hospital $^{2}$; Health Office of Florianópolis ${ }^{3}$; Federal \\ University of Santa Catarina Hospital ${ }^{4}$; Hemocenter \\ of Santa Catartina ${ }^{5}$, Florianópolis/SC; University of \\ São Paulo ${ }^{6}$, São Paulo/SP, Brazil
}

\begin{abstract}
$\mathrm{N}$-acetyl-L-cysteine (NAC) has been proposed as an additional therapeutic agent for AIDS patients because it reduces human immunodeficiency virus type 1 (HIV-1) replication in stimulated $\mathrm{CD}_{4}{ }^{+}$ lymphocytes, and it ameliorates immunological reactivity. In a randomized, 180-day, double-blind, placebo-controlled trial performed with $\mathrm{HIV}$-infected patients classified as $\mathrm{A} 2$ and $\mathrm{A3}$ according to the criteria of the Center for Disease Control and Prevention, we investigated the effects of oral administration of NAC on HIV-infected patients undergoing their first anti-retroviral therapy; viral load, $\mathrm{CD}_{4}^{+}$lymphocyte, lymphocyte viability and apoptosis, and TNF- $\alpha$ and IL-8 levels were determined. Sixteen patients who received anti-retroviral therapy plus a placebo formed the control group and the study group consisted of $\mathbf{1 4}$ patients who received anti-retroviral therapy and NAC supplementation. A significant decrease was seen in viral load, TNF- $\alpha$ and IL-8 levels, and lymphocyte apoptosis, and a significant increase was found in levels of $\mathrm{CD}_{4}^{+}$lymphocytes and lymphocyte viability in both groups after anti-retroviral treatment, but no measurable benefits of anti-retroviral therapy plus NAC oral supplementation $(600 \mathrm{mg} /$ day $)$ were found in relation to anti-retroviral therapy alone, and the baseline levels of cysteine and glutathione in plasma were not recovered by this treatment. In conclusion, the daily doses of NAC necessary for the total recuperation of plasma cysteine and glutathione levels in $\mathrm{HIV}$-infected patients and the additional benefits following the supplementation of NAC in patients submitted to anti-retroviral therapy, need to be studied further. Key Words: N-acetylcysteine; apoptosis; viability; HIV; glutathione; TNF- $\alpha$; IL-8.
\end{abstract}

$\mathrm{N}$-acetyl-L-cysteine (NAC), the acetylated variant of L-cysteine, is an excellent source of sulfhydryl ( $\mathrm{SH})$ groups, and it is converted in the body into metabolites capable of stimulating reduced glutathione (GSH) synthesis [1]. GSH is found in millimolar concentrations in all animal cells; it provides the principal intracellular defense against oxidative stress [2,3], and it participates in the detoxification

Received on 24 April 2004; revised 11 August 2004.

Address for correspondence: Dr. Aricio Treitinger. Departamento de Análises Clínicas, Centro de Ciências da Saúde, Universidade Federal de Santa Catarina. Campus Universitário - Trindade, Caixa Postal 476. Zip Code 88040900 -Florianópolis, SC, Brasil.E-mail: aricio@ccs.ufsc.br

The Brazilian Journal of Infectious Diseases 2004;8(5):363-371 (C) 2004 by The Brazilian Journal of Infectious Diseases and Contexto Publishing. All rights reserved. of many molecules [4]. Oral and intravenous administration of NAC has been clinically used as a mucolytic agent for treating pulmonary disorders [5-7] and is routinely administered to overcome pharmacologically-induced GSH deficiency due to acetaminophen overdose [8].

Besides its antioxidant action, glutathione is involved in multiple biological processes, and it has an important function in immune reactivity by modulating $\mathrm{T}$ cell proliferation, interleukin-2 synthesis and by increasing the cytotoxic and natural killer activities of T cells [912]. Several studies have shown that HIV-positive patients in different stages of infection have reduced cysteine and glutathione levels [13,14]. Moreover, in vitro studies have shown that NAC inhibits HIV replication induced by nuclear factor kappa B (NFКB) after TNF stimulation [15-16]. 
Several in vitro studies have demonstrated that $\mathrm{T}$ cells from HIV-infected patients are more susceptible to apoptosis, both in the resting and the activated state, than those from non-infected patients [17-20]. Malorni et al. [21] showed that NAC can inhibit TNF-induced apoptosis of HIV-chronically infected cells in vitro. Based on these data, the treatment of HIV-infected patients with NAC was proposed to determine if there were additional benefits for patients receiving, or not, anti-retroviral therapy [22,23]. Since then, NAC has been one of the drugs used as a coadjutant in the treatment of HIV infection in the USA and Europe [24].

The objective of this study was to evaluate the effects of orally administrated NAC (600 mg/day) on HIVinfected patients classified as A2 and A3, according to the criteria of the Center for Disease Control and Prevention [25], undergoing anti-retroviral therapy for the first time, by measuring lymphocyte viability and apoptosis, and TNF- $\alpha, \mathrm{IL}-8$, cysteine and glutathione levels in serum.

\section{Material and Methods}

\section{Patients}

This double-blind placebo-controlled study was performed from January 2000 to January 2002 with 30 patients selected and classified as A2 and A3 (1945 years old) according to the criteria of the Center for Disease Control and Prevention [25] by physicians from the Center of Infectious and Parasitic Diseases of the Nereu Ramos Hospital and from the STD/AIDS Section of Health Center II in Florianópolis, Santa Catarina, Brazil. Patients classified in other stages were excluded from this study. This study was approved by the Ethics Committee of the Federal University of Santa Catarina. Blood samples were taken after overnight fasting between 7:00 and 8:00 A.M. one day before the beginning of anti-retroviral therapy prescribed by the physicians and at 60,120 and 180 days of treatment. The control group consisted of 16 patients who received anti-retroviral therapy plus a placebo and the study group was constituted of 14 patients who received anti-retroviral therapy and
NAC oral supplementation (600 mg/day, Zambon Lab). The NAC oral supplementation was administered daily at 2:00 P.M. in a single dose. The anti-retroviral therapy was carried out according to the protocol described in Table 1.

\section{HIV-negative individuals group}

This group was constituted of seronegative healthy individuals with the same characteristics presented by the patients from the control group and the study group with respect to race, sex, age, and socio-economic conditions, in order to establish the median levels of cysteine and glutathione in serum, since reference levels for these constituents have not been established for the Brazilian population. The patients and the seronegative individuals were oriented to not make use of vitamin supplementation and to avoid a diet rich in vitamins $\mathrm{C}$ and $\mathrm{E}$. All patients and all seronegative individuals provided a written, informed consent and the study was conducted in accordance with the principles embodied in the Declaration of Helsinki.

\section{Viral load}

Viral load levels were measured using a commercially available kit, NASBA, from Organon Teknika, Boxtel, Netherlands. The limit of detection was 80 copies/mL plasma.

\section{$\mathrm{CD}_{4}^{+}$lymphocyte count}

The numbers of $\mathrm{CD}_{4}^{+}$lymphocytes were determined on a Becton/Dikinson FACScount ${ }^{\mathrm{TM}}$ flow cytometer using $\mathrm{CD}_{4} / \mathrm{CD}_{3}$ and $\mathrm{CD}_{8} / \mathrm{CD}_{3}$ antibodies from Becton/ Dickinson USA.

\section{Isolation of peripheral blood mononuclear cells}

Peripheral blood mononuclear cells (PBMC) were isolated from heparinized peripheral blood by centrifugation in a Ficoll-Hypaque (Pharmacia, Uppsala, Sweeden) density gradient and resuspended with RPMI 1640 medium containing 25 mM HEPES, 
2 mM L-glutamina (Sigma Chemical Company, Saint Louis, USA.), $10 \%$ heat inactivated fetal calf serum (Gibco, Paisley, Scotland, UK), $10 \mathrm{UI} / \mathrm{mL}$ penicillin, $10 \mu \mathrm{g} / \mathrm{mL}$ streptomycin and $2.5 \mu \mathrm{g} / \mathrm{mL}$ Fungison (Sigma Chemical Company, Saint Louis, USA). For the apoptosis assay, PBMC $\left(5 \times 10^{5}\right)$ were cultivated for $48 \mathrm{~h}$, at $37^{\circ} \mathrm{C}$, under a $5 \% \mathrm{CO}_{2}$ atmosphere.

\section{Evaluation of lymphocyte apoptosis and viability}

After maintaining PBMC in RPMI 1640 medium for $48 \mathrm{~h}$, the cells were washed twice with $1 \mathrm{~mL} \mathrm{PBS}$, pH 7.4 and labeled by incubation with $1 \mu \mathrm{M}$ calcein $\mathrm{AM}$ and $8 \mu \mathrm{M}$ ethidium bromide for $10 \mathrm{~min}$. Afterwards, the viability test was carried out with a flow cytometer (FACS Callibur, Becton Dickinson Immunocytometry Systems, San Jose, CA, USA), coupled to the software programs CELLQuest and PAINT-A-GATE, using the reagent kit LIVE/DEAD ${ }^{\circledR}$ (L-3224, Becton Dickinson Immunocytometry Systems, San Jose, CA, USA) containing calcein AM and ethidium homodimer-1 (EthD-1) (Molecular Probes Incorporation, Eugene, Oregon, USA). The viable cells retain polyanionic calcein, which emits an intense green fluorescence at $495 \mathrm{~nm}$, while the apoptotic cells allow the entrance of EthD-1, which binds to nucleic acids, originating a red fluorescence at $590 \mathrm{~nm}$. The evaluation of lymphocyte apoptosis and viability was performed after 48 hours, since after this time we observed elevated levels, but with a similar percentage distribution, of viable and apoptotic cells and a reduced number of unviable cells (Figure 1).

\section{Determination of TNF- $\alpha$ and IL-8 levels}

The plasma levels of TNF- $\alpha$ e IL- 8 were determined by solid phase immunometric chemiluminescent assays (IMMULITE® ${ }^{\circledR}$ TNF- $\alpha$ and IMMULITE® IL-8, DPC $®$, Diagnostic Products Corporation, Los Angeles, USA).

\section{Determination of cysteine and glutathione levels}

The serum levels of cysteine and glutathione were determined by high performance capillary electrophoresis according to Vecchione et al. [26] with the Biofocus ${ }^{\circledR}$ (Bio Rad Laboratories Incorporation, California, USA) instrument.

\section{Statistical analysis}

The hypotheses of constancy, coincidence and parallelism that were assumed in the evaluation of the effects of the variables, treatment time, treatment type, and the interaction between both variables, were tested by multivariate repeated measures analysis of variance through the tests Wilks' Lambda, Pillai's Trace, Hotelling-Lawley Trace and Roy's Greatest Root with the SPSS $10 \AA$ and SAS $8 \mathrm{e} \AA$ software programs. The significant differences were tested by the Helmert, Profile and Difference contrast tests. The significance level considered was $\mathrm{p}<0.05$.

\section{Results}

\section{Viral load}

The plasma viral load from randomly selected patients was determined at baseline and after 60, 120 and 180 days of treatment. When the viral load after 60, 120 and 180 days of treatment was compared with the respective baseline values a significant decrease was noted in both groups $(p<0.05)$. No difference was noted between the study and control groups ( $\mathrm{p}=0.2587)$ (Figure 2A).

\section{$\mathrm{CD}_{4}^{+}$lymphocytes}

Significant changes in $\mathrm{CD}_{4}^{+}$lymphocytes were found in both groups after 60, 120 and 180 days when we compared these levels with the respective baseline $(\mathrm{p}<0.05)$. No significant difference was noted between the study and control groups $(\mathrm{p}=0.370)$ (Figure 2B).

\section{Lymphocyte viability and lymphocyte apoptosis}

A significant increase in lymphocyte viability was observed after 120 and 180 days of treatment $(p<0.05$, 
Table 1. Anti-retroviral therapy protocol

\begin{tabular}{lll}
\hline Anti-retroviral treatment & Control Group n=16 & Study Group n=14 \\
\hline AZT + 3TC + NVP & 11 & 8 \\
AZT + ddI + NVP & 2 & 4 \\
AZT + 3TC + ddI & 1 & 1 \\
AZT + 3TC & 2 & 1 \\
\hline
\end{tabular}

AZT - azidothymidine; 3TC - lamivudine; NVP - nevirapine; ddI - didanosine. The control group was treated with anti-retroviral therapy; the study group was treated with anti-retroviral therapy plus N-acetylcysteine.

Figure 1. Lymphocyte distribution obtained by PAINT A GATE software according to the staining intensity with calcein and or homodimer of ethidium. Viable lymphocytes (green), apoptotic lymphocytes (black) and unviable lymphocytes (red).

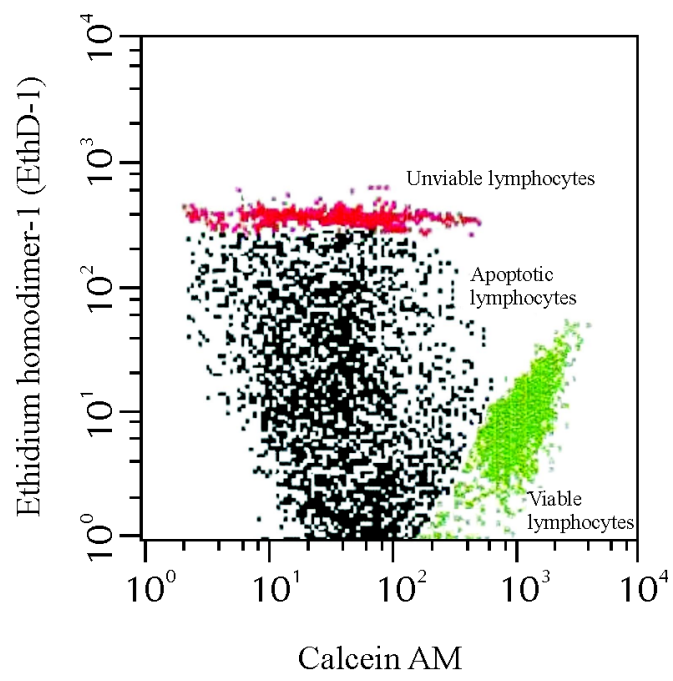

Figure 2. Changes in the viral load (A) and in lymphocyte count (B) during 180 days of treatment with antiretroviral therapy plus placebo (control group) and with anti-retroviral therapy plus $600 \mathrm{mg} /$ day N-acetyl-Lcysteine (NAC) oral supplementation (study group). $* \mathrm{p}<0.05$ compared to baseline levels (day 0 ) within the respective group.
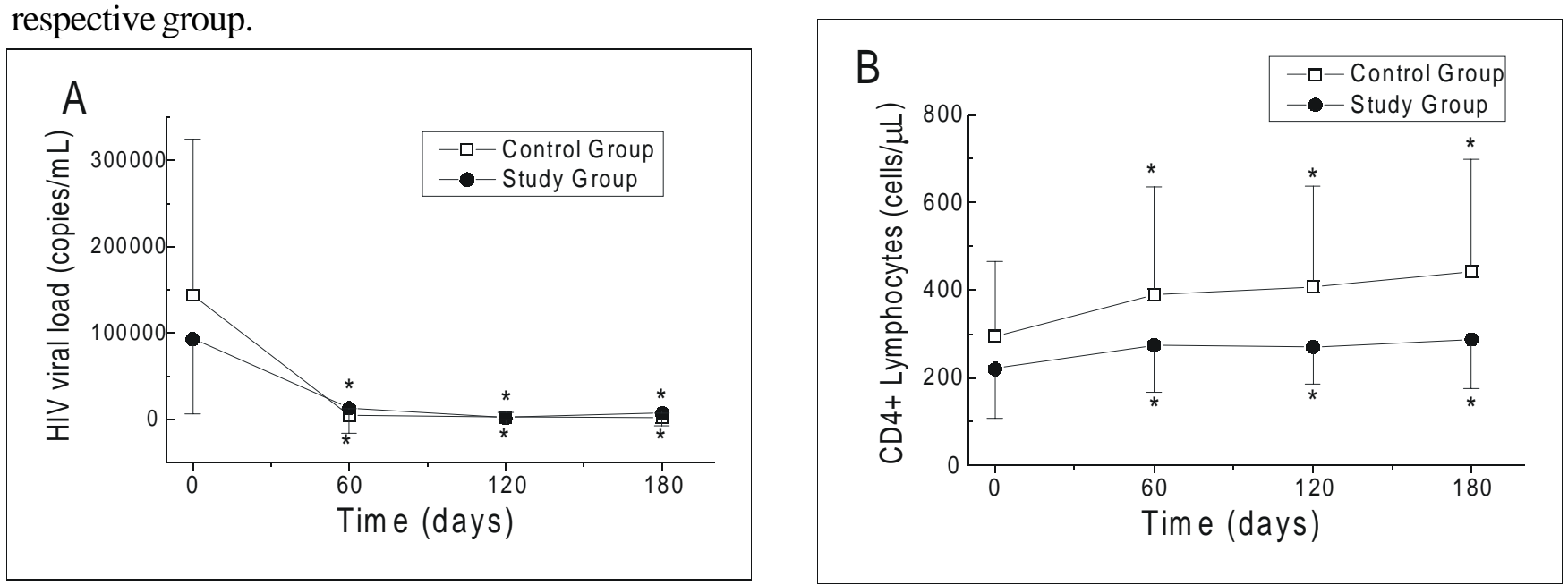
Figure 3A). Significantly decreased levels of lymphocyte apoptosis were noted after 180 days of treatment in both groups when we compared these levels with the respective baselines $(p<0.05$, Figure 3B). No additional effect of anti-retroviral therapy plus NAC supplementation was found on lymphocyte viability $(p=0.4397$, Figure $3 A$ ) or on lymphocyte apoptosis ( $\mathrm{p}=0.9407$, Figure $3 \mathrm{~B}$ ) in comparison to antiretroviral therapy alone.

\section{$T N F-\alpha$ and $I L-8$}

After 60 days of treatment, serum levels of TNF- $\alpha$ (Figure 4A) and IL-8 (Figure 4B) decreased significantly in comparison to the respective baseline $(\mathrm{p}<0.05)$. When we compared the levels of TNF- $\alpha$ and IL- 8 after 120 and 180 days of treatment to the levels after 60 days of treatment, a significant decrease was noted $(\mathrm{p}<0.05)$. After 180 days of treatment the decrease in the levels of TNF- $\alpha$ and IL- 8 had a significance of $\mathrm{p}<0.0001$ in comparison to the respective baseline in both groups. No additional effect of the anti-retroviral therapy plus NAC supplementation was found for TNF- $\alpha(p=0.6626$, Figure 4A) or IL-8 levels ( $\mathrm{p}=0.4311$, Figure $4 \mathrm{~B}$ ) in relation to anti-retroviral therapy alone.

\section{Cysteine and glutathione}

Serum levels of cysteine and glutathione after 60, 120 and 180 days of treatment $(p<0.05)$ were significantly enhanced in relation to the respective baselines, for both the control group and the study group (Figures 5A and 5B). The statistical analysis showed a significant difference between the effects of the treatments that the study and control groups were submitted to $(\mathrm{p}=0.0089$ and $\mathrm{p}=0.0234$, for cysteine and glutathione, respectively, Figures 5A and 5B).

Although the concentrations of cysteine and reduced glutathione were significantly increased by NAC supplementation, the serum levels of these thiols did not reach the values observed in a group of HIVnegative individuals (cysteine: 209.76 $\pm 39.17 \mathrm{uM}$; glutathione: $4.812 \pm 1.687 \mathrm{uM} ; \mathrm{n}=12$ ).

\section{Discussion}

NAC oral supplementation (600 mg/day) in HIVpositive patients undergoing their first 180-day antiretroviral treatment did not result in significant additional effects on serum levels of viral load, $\mathrm{CD}_{4}^{+}$lymphocytes, TNF- $\alpha$, IL-8, lymphocyte apoptosis and lymphocyte viability. Our results did not agree with previous reports, which indicate that NAC supplementation improves some immune and biochemical markers of infection in HIV-infected patients [27-30]. In our study, in which the blood samples were collected 17-18h after taking the last NAC dose, the plasma levels of the cysteine and glutathione were not normalized with NAC supplementation (600 mg/day), taking plasma levels of these compounds in HIV-negative patients as a reference. Thus, it is possible that plasma cysteine and glutathione levels did increase significantly or did normalize $6 \mathrm{~h}$ after taking NAC, but decreased significantly after overnight fasting: this would be in agreement with the findings of previous studies that were carried out on healthy human volunteers and paracetamol-challenger subjects, indicating that the elevated thiol levels after NAC administration returned to baseline levels after $8 \mathrm{~h}$ [7,31-33]. However, it is also possible that our patients from the study group did not recover the normal levels of cysteine and glutathione because of the low bioavailability of NAC, because the dose administered was insufficient [32], or because the daily dose was taken only once a day.

In a recent study conducted with 20 patients, supplementation with $600 \mathrm{mg} /$ day NAC resulted in an increase in the $\mathrm{CD}_{4}^{+}$lymphocyte count [34]. However, we found that the addition of NAC ( $600 \mathrm{mg} /$ day) to anti-retroviral therapy did not improve the recovery of the immune cellular defense system as a consequence of decreased apoptosis of $\mathrm{CD}_{4}^{+}$lymphocytes, as had been suggested [28], while an decrease in apoptosis levels and an increase in $\mathrm{CD}_{4}^{+}$lymphocyte counts was noted in both study groups.

The partial recovery of the immune cellular defense system that was observed must be due to the antiretroviral therapy, which resulted in a significant decrease in the viral load levels. This decrease in turn 
Figure 3. Variation in the lymphocyte viability (A) and in apoptosis of lymphocytes (B) during 180 days of treatment with anti-retroviral therapy plus placebo (control group) and with anti-retroviral therapy plus $600 \mathrm{mg} /$ day NAC oral supplementation (study group). ${ }^{*} \mathrm{p}<0.05$ compared to baseline levels (day 0 ) within the respective group.
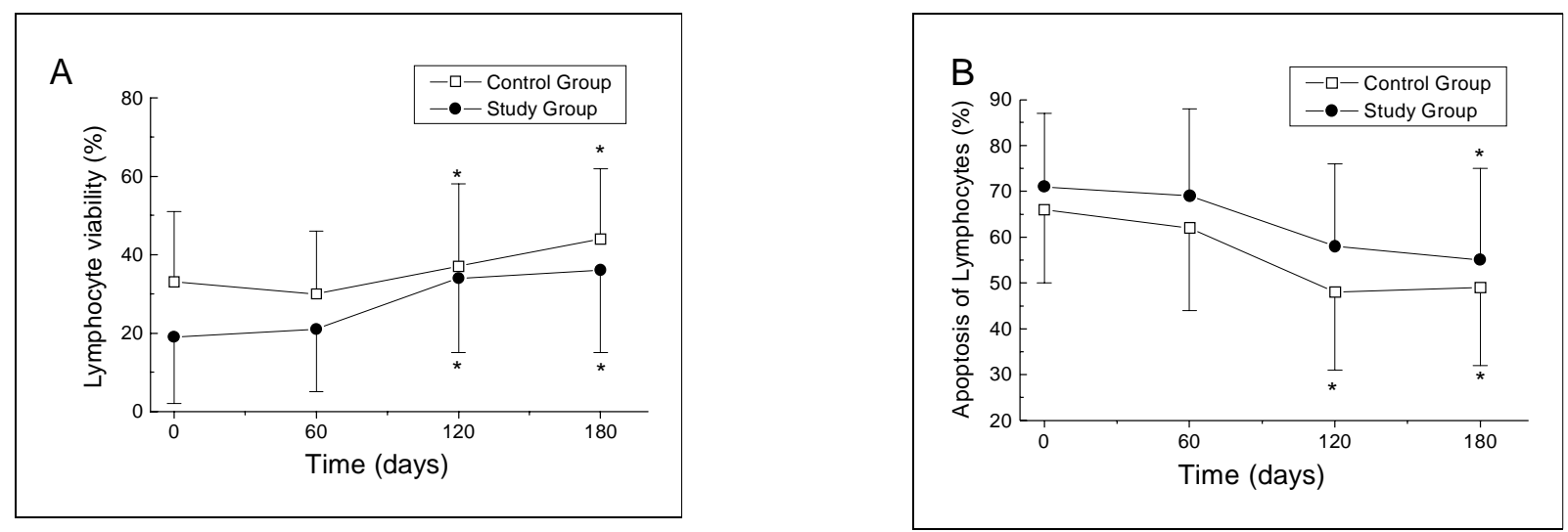

Figure 4. Changes in the plasmatic levels of TNF- $\alpha$ (A) and IL-8 (B) during 180 days of treatment with antiretroviral therapy plus placebo (control group) and with antiretroviral therapy plus $600 \mathrm{mg} /$ day NAC oral supplementation (study group). ${ }^{*} \mathrm{p}<0.05$ compared to baseline levels (day 0 ) within the respective group.
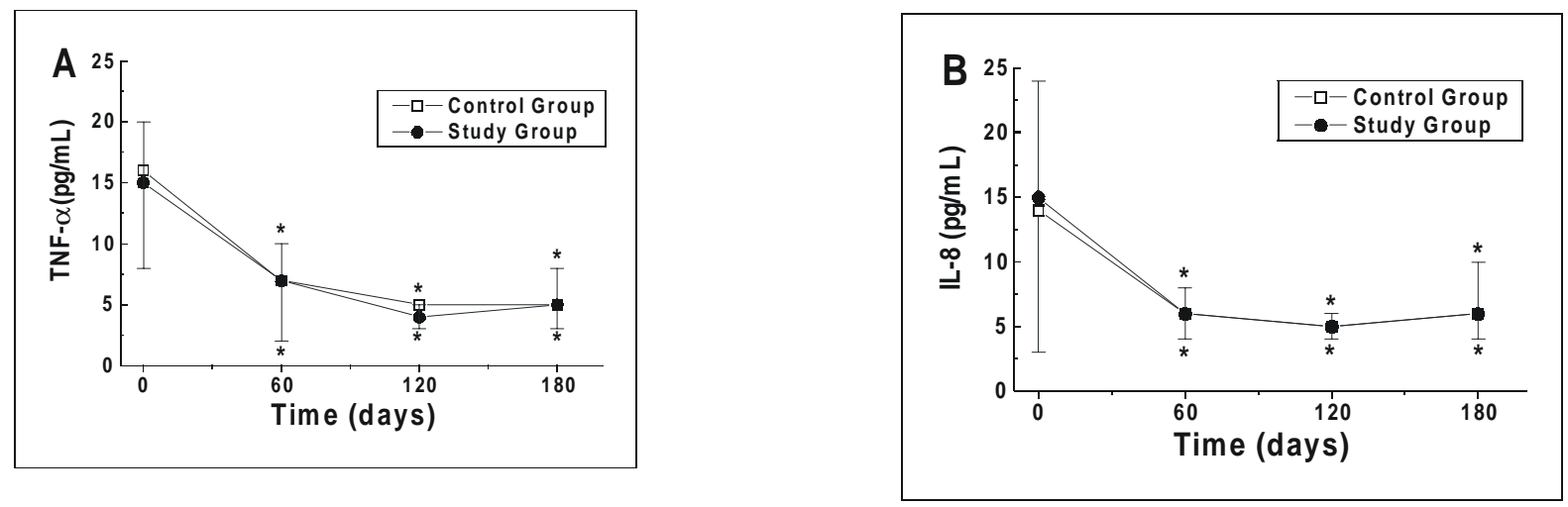

Figure 5. Changes in the plasmatic levels of cysteine (A) and glutatione (B) during 180 days of treatment with anti-retroviral therapy plus placebo (control group) and with anti-retroviral therapy plus $600 \mathrm{mg} /$ day NAC oral supplementation (study group). $* \mathrm{p}<0.05$ compared to baseline levels (day 0 ) within the respective group.
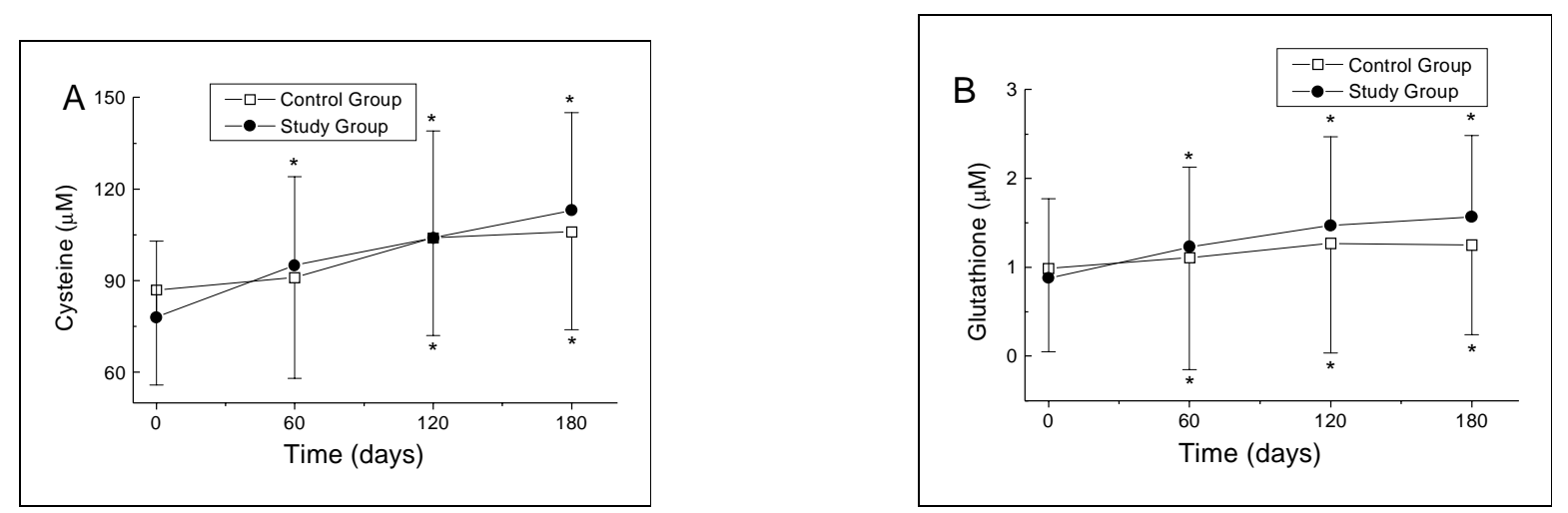

www.bjid.com.br 
leads to a reduction in the activation levels of the cells of the humoral immune defense system, and consequently, a decrease in the expression of Fas-L, TNF- $\alpha$ [35], responsible for the activation of the $\mathrm{CD}_{4}^{+}$ lymphocyte apoptosis [36]. The decrease in the viral load levels also results in a reduction in the HIVinfection of other $\mathrm{CD}_{4}^{+}$lymphocytes, thereby decreasing the formation of syncytium [37,38]. More recent studies have shown that apoptosis in HIVglycoprotein-expressing cells in vitro is mainly caused by syncytium formation, which amplifies small amounts of spontaneous apoptosis, occurring as a consequence of marked signals [39].

The increase attained in the concentrations of cysteine and glutathione in both the groups, which probably occurred as a consequence of reduction in the viral load could be due to a reduction in the oxidative stress by the preservation of the activities of antioxidant enzymes [40] and by the normalization of cytokine synthesis [41] (Figures 5A, 5B and 2A, respectively).

The patients in our study were submitted to antiretroviral therapy that did not include protease inhibitors because the protease inhibitors reduce the expression and activation of caspases that would inhibit lymphocyte apoptosis $[42,43]$, and the therapy that was utilized has consequently been frequently selected recently as the first anti-retroviral therapy.

Results from several preliminary investigations by different laboratories [27,30, 44-49] have suggested that NAC therapy may have beneficial effects on HIVseropositive patients. Chiba et al. [46] showed that a recovery of cysteine and glutathione levels contributed to reduced $\mathrm{CD}_{4}^{+}$apoptosis. Äkerlund and colleagues [29] showed that oral treatment with NAC only, $(800 \mathrm{mg} /$ day), decreased the plasma concentrations of TNF- $\alpha$, slowed the decrease in the $\mathrm{CD}_{4}^{+}$lymphocyte count and normalized the plasma levels of cysteine. Olivier [28] reported an increased tendency of lymphocytes from HIV-infected patients to undergo apoptosis, and reported that NAC treatment with variable oral doses (600 to $1,800 \mathrm{mg} /$ day) ameliorated this phenomenon, but the cysteine and glutathione levels were not determinates. Unfortunately, this study was not performed in a randomly controlled double-blind fashion. Look et al. [45] studied the effects of NAC in combination with sodium selenite in a randomized placebo-controlled trial. Using an NAC oral dose of $1,800 \mathrm{mg}$ /day, the authors observed an increase in the percentage of $\mathrm{CD}_{4}$ cells, which resulted in a significant increase in the $\mathrm{CD}_{4} / \mathrm{CD}_{8}$ cell ratio. However, the oral treatment with $1,800 \mathrm{mg}$ of NAC was not effective in elevating plasma glutathione levels. Müller et al. [47], in a short-term, high dose combination treatment with NAC and vitamin $\mathrm{C}$, found no significant changes in viral load, $\mathrm{CD}_{4}^{+}$ lymphocyte counts, or in lymphocyte apoptosis. Breitkreutz et al. [48], in a randomized placebocontrolled study, noted an increase in the natural killer activity of lymphocytes. Herzenberg and colleagues [30] and De Rosa et al. [50] in randomized trials with followup demonstrated that oral administration of NAC $(4 \mathrm{~g}$ to $8 \mathrm{~g} /$ day) replenished glutathione and improved survival rates. Clotet et al. [27] reported that oral doses of $3.2 \mathrm{~g} /$ day, in combination with zidovudine, did not cause any change in $\mathrm{CD}_{4}^{+}$lymphocyte counts during a follow-up period of six months.

In our study the oral dose of NAC (600 mg/day) did not result in normalization of cysteine and glutathione plasma levels. This indicates that higher doses, and more daily doses, of NAC must be necessary to bring about the normalization of these levels and to achieve the possible additional benefits for the immune response system by inhibiting the increase in $\mathrm{CD}_{4}^{+}$apoptosis and the reduction in lymphocyte viability. However, large oral doses of NAC can result in a wide variety of side effects, including nausea, vomiting, gastrointestinal disturbances, rashes, pruritis, angioedema, bronchiospasm, tachycardia, hypotension and hypertension [51]. Some of these side effects are the same as those observed in patients submitted to their first anti-retroviral therapy [27]. It is therefore possible that in HIV-soropositive patients submitted to their first anti-retroviral therapy, the side effects following the administration of large doses of NAC may exacerbate the side effects following antiretroviral therapy [52-56]. This may result in an increase in the numbers of patients who abandon the anti-retroviral therapy within the first month. 
In conclusion, the daily doses of NAC necessary for the total recuperation of plasma cysteine and glutathione levels in HIV-infected patients and the additional benefits following the supplementation of NAC to patients submitted to anti-retroviral therapy, need to be studied further.

\section{References}

1. De Vries N., De Flora S. N-Acetyl-1-Cysteine. J Cell Biochem 1993;17F:S270-7.

2. Shan X.Q., Aw T.Y., Jones D.P. Glutathione-dependent protection against oxidative injury. Pharmacol Ther 1990;47:61-71.

3. Meister A. Glutathione-ascorbid acid antioxidant system in animals. J Biol Chem 1994;269:9397-400.

4. Thomas S.H. Paracetamol (acetaminophen) poisoning. Pharmacol Ther 1993;60:91-120.

5. Olsson B., Johanson M., Gabrielson J., Bolme P. Pharmacokenitics and bioavailability of reduced and oxidized N-acetylcysteine. Eur J Clin Pharmacol 1988;34:77-82.

6. Ventresca G.P., Cicchetti V., Ferrari V. Drugs in Bronchial Mucology. pp.77-102. New York: Raven Press; 1989.

7. Burgunder J.M., Varriale A., Lauterburg B.H. Effect of Nacetylcysteine on plasma cysteine and glutathione following paracetamol administration. Eur J Clin Pharmacol 1989;36:127-31.

8. Smilkstein M.J., Knapp G.L., Kulig K.W., Rumack B.H. Efficacy of oral $\mathrm{N}$-acetylcysteine in the treatment of acetaminophen overdose. Analysis of the national multicenter study (1976 to 1985). N Engl J Med 1988;319:1557-62.

9. Beutler E. Nutritional and metabolic aspects of glutathione. Annu Rev Nutr 1989;9:287-302.

10. Dröge W., Schulze-Osthoff K., Mihm S., et al. Functions of glutathione and glutathione disulfide in immunology and immunopathology. FASEB J 1994;8:1131-8.

11. Staal F.J., Roederer M., Israelski D.M., et al. Intracellular glutathione levels in $\mathrm{T}$ cell subsets decrease in HIVinfected individuals. AIDS Res Hum Retroviruses 1992;8:305-11.

12. Staal F.J. Glutathione and HIV infection: reduced reduced, or increased oxidized? Eur. J. Clin. Invest 1998;28:194-6.

13. Dröge W., Eck H.P., Naher H., et al. Abnormal amino-acid concentrations in the blood of patients with acquired immunodeficiency syndrome (AIDS) may contribute to the immunological defect. Biol Chem Hoppe Seyler 1988;369:143-8.
14. Eck H.P., Gmunder H., Hartmann M., et al. Low concentrations of acid-soluble thiol (cysteine) in the blood plasma of HIV-1-infected patients. Biol Chem Hoppe Seyler 1989;370:101-8.

15. Kalebic T., Kinter A., Poli G., et al. Suppression of human immunodeficiency virus expression in chronically infected monocytic cells by glutathione, glutathione ester, and N-acetylcysteine. Proc Natl Acad Sci USA 1991;88:986-90.

16. Roederer M., Staal F.J.T., Raju P.A., et al. Cytokinestimulated human immunodeficiency virus replication is inhibited by N-acetyl-L-cysteine. Proc Natl Acad Sci USA 1990;87:4884-8.

17. Meyaard L., Otto S.A., Jonker R.R., et al. Programmed death of $\mathrm{T}$ cells in HIV-1 infection. Science 1992;257:217-9.

18. Gougeon M.L., Montagnier L. Apoptosis in AIDS. Science 1993;260:1269-70.

19. Finkel T.H., Banda N.K. Indirect mechanisms of HIV pathogenesis: how does HIV kill T cells? Curr Opin Immunol 1994;6:605-15.

20. Muro-Cacho C.A., Pantaleo G., Fauci A.S. Analysis of apoptosis in lymph nodes of HIV-infected persons. Intensity of apoptosis correlates with the general state of activation of the lymphoid tissue and not with stage of disease or viral burden. J Immunol 1995; $154: 5555-66$.

21. Malorni W., Rivaben R., Santini M.T., Donelli G. Nacetylcysteine inhibits apoptosis and decreases viral particles in HIV-chronically infected U937 cells. FEBS Lett 1993;327:75-8.

22. Dröge W., Eck H.P., Mihm S. HIV-induced cysteine deficiency and T-cell dysfunction-a rationale for treatment with $\mathrm{N}$-acetylcysteine. Immunol Today 1992;13:211-4.

23. Ho W.Z., Douglas S.D. Glutathione and N-acetylcysteine suppression of human immunodeficiency virus replication in human monocyte/macrophages in vitro. AIDS Res Hum Retroviruses 1992;8:1249-53.

24. Dröge W., Breitkreutz R. N-acetyl-cysteine in the therapy of HIV-positive patients. Curr Opin Clin Nutr Metab Care 1999;2;493-8.

25. CDC Centers for Disease Control. 1993 revised classification system for HIV infection and expanded surveillance case definition for AIDS among adolescents and adults. MMWR Mor. Mortal Wkly Rep 1992; 41:1-19.

26. Vecchione G., Margaglione M., Grandone E., et al. Determining sulfur-containing amino acids by capillary electrophoresis: a fast novel method for total homocyst(e)ein human plasma. Electrophoresis 1999;20:569-74. 
27. Clotet B., Gomez M., Ruiz L., et al. Lack of short-term efficacy of N-acetyl-L-cystine in human immunodeficiency virus-positive patients with $\mathrm{CD}_{4}$ cell counts $<250 / \mathrm{mm}^{3}$. J Acquired Imune Def Syndr Hum Retrovirol 1995;9:957-61.

28. Olivier R. Flow cytometry technique for assessing effects of $\mathrm{N}$-acetilcysteine on apoptosis and cell viability of human immunodeficiency virus-infected lymphocytes. Methods Enzimol 1995;251:270-8.

29. Äkerlund B., Jarstrand C., Lindeke B., et al. Effect of Nacetylcysteine (NAC) treatment on HIV-1 infection: A double-blind placebo-controlled trial. Eur J Clin Pharmacol 1996;50:457-61.

30. Herzenberg L.A., De Rosa S.C., Dubs J.G., et al. Glutathione deficiency is associated with impaired survival in HIV disease. Proc Natl Acad Sci USA 1997;94:196719-72.

31. Cotgreave I.A. N-acetylcysteine pharmacological considerations and experimental applications. Adv Pharmacol 1987;38:205-27.

32. De Caro L., Ghizzi A., Costa R., et al. Pharmacokinetics and bioavailability of oral acetylcysteine in healthy volunteers. Arzneimittelforschung 1989;39:382-6.

33. Helbling B., von Overbeck J., Lauterburg B.H. Decreased release of glutathione into the systemic circulation of patients with HIV infection. Eur J Clin Invest 1996;26:38-44.

34. Spada C., Treitinger A., Reis M., et al. The effect of Nacetylcysteine supplementation upon viral load, $\mathrm{CD}_{4}$, $\mathrm{CD}_{8}$, total lymphocyte count and hematocrit in individuals undergoing antiretroviral treatment. Clin Chem Lab Med. 2002;40:452-5.

35. Badley A.D., Pilon A.A., Landay A., Lynch D.H. Mechanisms of HIV-associated lymphocyte apoptosis. Blood 2000;96;2951-64.

36. Patki A.H., Georges D.L., Lenderman M.M. CD4+ T cells counts, spontaneous apoptosis, and Fas expression in peripheral blood mononuclear cells obtained from human immunodeficiency virus type 1 infected subjects. Clin Diagn Lab Immunol 1997;4;736-41.

37. Lifson J.D., Feinberg M.B., Reyes G.R., et al. Induction of $\mathrm{CD}_{4}$-dependent cell fusion by the HLTV-III/LAV envelope glycoprotein. Nature 1986;323:725-8.

38. Sodroski J., Goh W.C., Rosen C., et al. Role of the HLTVIII/LAV envelope in syncytium formation and citopathicity. Nature 1986;322:470-4.

39. Scheller C., Jassoy C. Syncytium formation amplifies apoptotic signals: a new view on apoptosis in HIV infection in vitro. Virology 2001;30:48-55.

40. Pastor A., Collado P.S., Almar M., Gonzalez-Gallego J. Antioxidant enzyme status in biliary obstructed rats: effects of N-acetylcysteine. J Hepatol 1997;27;363-70.
41. Baier J.E., Neumann H.A., Moeller T., et al. Radiation protection through cytokine release by $\mathrm{N}$ acetylcysteine Strahlenther Onkol 1996;172;91-8.

42. Sloand E.M., Kumar P.N., Kim S., et al. Human immunodeficiency virus type 1 protease inhibitor mmodulates activation of peripheral blood $\mathrm{CD}_{4}^{+} \mathrm{T}$ cells and decreases their susceptibility to apoptosis in vitro and in vivo. Blood 1999;94;1021-7.

43. Weichold F.F., Bryant J.L., Pati S., et al. HIV 1 protease inhibitor Ritonavir modulates susceptibility to apoptosis of uninfected T cells. J Hum Virol 1999;2;261-9.

44. Simon G., Moog C., Obert G. Effects of glutathione precursors on human immunodeficiency virus replication. Chem Biol Interact. 1994;91;217-24.

45. Look M.P., Rockstroh J.K., Rao G.S., et al. Sodium selenite and $\mathrm{N}$-acetylcysteine in antiretroviral-naive HIV-1infected patients: a randomized, controlled pilot study. Eur J Clin Invest. 1998;28:389-97.

46. Chiba T., Takahashi S., Sato N., et al. Fas-mediated apoptosis is modulated by intracellular glutathione in human T cells. Eur J Immunol. 1996;26;1164-9.

47. Muller F., Svardal A.M., Nordoy I., et al. Virological and immunological effects of antioxidant treatment in patients with HIV infection. Eur J Clin Invest. 2000;30:905-14.

48. Breitkreutz R., Pittack N., Nebe C.T., et al. Improvement of immune functions in HIV infection by sulfur supplementation: two randomized trials. J Mol Med. 2000;78:55-62.

49. Sprietsma J.E. Cysteine, glutathione (GSH) and zinc and copper ions together are effective, natural, intracellular inhibitors of (AIDS) viruses. Med Hypotheses 1999;52;529-38.

50. De Rosa S.C., Zaretsky M.D., Dubs J.G., et al. Nacetylcysteine replenishes glutathione in HIV infection. Eur J Clin Invest 2000;30;915-29.

51. Kelly G.S. Clinical applications of N-acetylcysteine. Altern Med Rev 1998;3: 114-27.

52. Ippolito G., Puro V. Zidovudine toxicity in uninfected healthcare workers. Italian Registry of Antiretroviral Prophylaxis. Am J Med 1997; 102;58-62.

53. Moyle G.J., Nelson M.R., Hawkins D., Gazzard B.G. The use and toxicity of didanosine (ddI) in HIV antibodypositive individuals intolerant to zidovudine (AZT) Q J Med 1993;86;155-63.

54. De Wit S., Sternon J., Clumeck N. [Nevirapine (Viramune): a new HIV inhibitor] Rev Med Brux 1999;20;95-9.

55. Podzamczer D., Fumero E. The role of nevirapine in the treatment of HIV-1 disease. Expert Opin Pharmacother 2001;2;2065-78.

56. Fuchs J.E. Jr, Pollard R.B. Stavudine: A Review. Braz J Infect Dis 1998; 2 : 10-7. 